\title{
An Overview of SME Sector and Examination of Banks Lending to SMEs: A Case Study of Jodia Bazaar - Karachi
}

\author{
Fiaz Ahmad \\ Mr. Abdus Salam
}

\begin{abstract}
SMEs are considered as driving force for the economy both in developing as well as in developed countries. In the given economic structure, no one can deny the importance of Small and Medium Enterprises. They are contributing in employment generation, GDP growth, poverty reduction and earning foreign exchange for the country by boosting its exports. Pakistani economy has good potential for the growth of SME sector but still they are unable to get the maximum benefit from this sector. There are multiple reasons behind this, including lack of good policies, current law and order situation as well as political instability in the country. One important problem faced by SMEs is unavailability of finances from the formal sources including banking channels. SBP and other specialized institutions like SME Bank, SMEDA is playing major role in the development of SME sector but still there is a lot of cushion available. Jodia Bazaar is considered as one of the major whole sale markets in Karachi. It consists of thousands of SMEs which includes whole sellers, retailers, importers, exporters, grain traders etc. Due to large potential in this market almost every bank has its presence in this market in the form of branch at Jodia Bazaar. If we look at the credit portfolio of these branches, we will come to know that the contribution of SME portfolio in their major credit portfolio is very small. We have conducted our research to know the factors due to which banks are reluctant to have exposure in the SME sector, especially in the Jodia Bazaar. Data have been collected from fifteen branches of banks located in Jodia Bazaar. Results are analyzed through Pie Charts. This research will be helpful for the Banking professionals, especially associated with credit departments and those who want to enhance the credit portfolio of the Branch in the Small and Medium Enterprises. Results show that Banks in Jodia Bazar are reluctant to take exposure in SME sector due to number of reasons, mainly due to unavailability of correct information, maintenance of proper accounts and availability of trained professionals hired by SMEs. Results also show that some banks have not developed specialized products for SMEs and they are not properly marketing the same.
\end{abstract}

Keywords: SMEs, Jodia Bazaar, Banks' Lending, Pakistan's economy

\section{1- Introduction}

\section{1 -Background of the Study}

SMEs are considered as locomotive sector of the economic growth both in developing as well as in the developed countries. There is no second opinion on the importance of small and medium enterprises in the developing and developed countries. As SMEs account for 30-40 per cent of employment in the country and are labor intensive, the consequential rise in its productivity and efficiency would make a significant contribution in accelerating employment generation, GDP growth and poverty reduction.

SMEs also contribute to exports and assimilation of new technology in the production process as it would make their products competitive in the international markets. Like many developing countries, in Pakistan, there are 3.2 million Economic Establishments, $44 \%$ in rural areas and 56\% in the urban areas (www.sbp.org.pk).

Fiaz Ahmad is an MS (MS) student at SZABIST, Karachi, fiaz_ask@yahoo.com

Mr. Abdus Salam is Deputy Director, Statistics \& Warehouse Dept., State Bank of Pakistan, Karachi, abdussalamsbp@gmail.com 


\subsection{Problem Statement}

The research will contain the overview of SME sector in the context of economic growth, contribution in GDP, poverty reduction and potential of future growth in SMEs.

The banking industry's exposure towards the SME sector is the second largest after corporate finance. In Pakistan, corporate sector takes away the major chunk of credit extended by the banking system.

Jodia Bazaar is considered as major whole sale market of Pakistan which contains whole sellers, importers, exporters and general traders. This market has large potential for SMEs financing but still a large portion of this market is unaddressed, despite the fact that this area contains the presence of every commercial Bank, either Islamic or conventional. The researcher wants to study that despite so much potential, why the banks are reluctant to have exposure in this market and what are the main issues for lending to SMEs, particularly in this vicinity of Jodia Bazaar.

\subsection{Research Objectives}

- An overview of SME Sector in Pakistan in the context of economic growth, contribution in GDP, poverty reduction and potential of future growth in SMEs.

- Role of SBP and other specialized institutions in the development of SME Sector.

- To analyze the Banks lending to SME Sector.

- To study the specialized products developed by different Banks for SME Sector.

- To study the Major issues faced by the Commercial Banks in financing to SMEs particularly in the Jodia Bazaar.

\subsection{Research Methodology}

The research is qualitative in nature and a synopsis of SME as well as Banking sector will be carried out especially in terms of financing. A questionnaire was developed and circulated among all the commercial banks having their presence in the Jodia Bazaar. Results were analyzed through pie charts and bar graphs to identify the major issues faced by these Banks while lending to SMEs in this vicinity.

Primary data will be collected through questionnaire while secondary data will be collected from different journals, newspapers and already published researches on SME sector. Researcher will also visit the specialized institutes like SME bank and Small \& Medium Enterprises Development Authority for collection of data. Also various websites will be reviewed to find the useful information on the subject.

\subsection{Research Limitations}

As SME sector is one of the largest sector in Pakistan, keeping in view the time frame the researcher will constraint itself only to the overview of performance of SME Sector and particularly issues faced by Banks in lending to SMEs in the vicinity of Jodia Bazaar.

\section{2- Banking Sector in Pakistan}

\subsection{Overview of Banking Industry}

The banking sector has performed well in last few years; the financial sector has seen tremendous growth in the past few years and has been the driving force behind sustained above average service growth. Banking sector profitability has broken its own records year after year (Ministry of Finance, 2007). 


\section{2- Current Challenges faced by Banking Industry}

The outgoing fiscal year 2008-09 proved critical for banks as their profits and deposits fell, while the bankers and analysts see no chance of recovery of economy and banks profits during the new fiscal year since demand is falling and NPLs are rising.

How the next year would be no one can predict, but most of the bankers said that it would be another year of low demand and poor performance both for the economy as well as for the banking industry.

Banks will remain under pressure during the new fiscal year as demand is at very low level. A number of worries go with the new fiscal year due to the poor economic growth. The textile sector was in trouble, they were not getting orders, which reduced liquidity demand from the banking sector.

Many bankers expressed their fear regarding the rising non-performing loans (NPLs), which crossed over Rs100 billion during the year and they felt that this figure would further rise next year.

Law and order situation is also a serious source of concern for economy, which slashes demands. Foreign buyers prefer to go to India and Bangladesh, instead of coming to Pakistan, due to operation against militants in the northern part of the country. (SME Newsletter, Issue No. 15, BAL 2009)

\section{3- Role of SBP in Banking Sector}

State Bank of Pakistan is the regulatory authority for the banking sector and it has separate guidelines for the Corporate, SMEs, Consumers, Microfinance, Agriculture Financing and Export Financing.

Regulatory measures are now in place to curb practices of anti-money laundering as well as terrorist financing.

\section{4- Products offered by Banking Industry to SME Sector}

State Bank of Pakistan is playing major role in promoting the SME sector in Pakistan. SBP forced all banks to develop some specific products to increase SME financing. Resultantly, banks developed SME products details of which are given below:

\section{United Bank Ltd}

- Rice Paddy Advances

- Cotton Ginners Advances

- Credit Facilities against liquid securities

- Running Finance For SMEs

\section{Bank Alfalah Ltd}

- Alfalah Karobar Finance

- Alfalah Milkiat Finance

- Alfalah Quick Finance

\section{Standard Chartered Bank Ltd}

- Tana Bana ( For Textile weavers)

- Rang Hi Rang ( For Textile dyers)

- Kissan Card (Agri Sector)

- Agri Deal (Agri Sector)

\section{Bank of Punjab}


- Lady entrepreneur Financing Scheme

- Karobar Bahraho Scheme

- Franchise Financing Scheme

- Atlas Honda Dealer Financing Scheme

- Millat Tractors Dealer Financing Scheme

\section{Citi Bank}

- Running Finance for SMEs

- Term loans for SMEs

\section{NIB Bank Ltd}

- Small Business Loans

- Salaam Business Loans

\section{SME Bank Ltd}

- Smart Loans

- Asset Finance

- Running Finance for SMEs

\section{Atlas Bank Ltd}

- Agri Line

The above banks are offering specialized products in the SME sector. Other banks, especially some big banks like MCB, HBL NBP are also offering regular products to SME sector.

\section{3- SME Sector in Pakistan}

\section{1- An Overview of SMEs}

One of the best characteristics of a growing and healthy economy is the blooming SME sector. Small and medium enterprises play an important role in the development of country in many ways. They also create employment in the rural and urban areas of the country; large numbers of people are dependent upon this sector, directly or indirectly. Most of the current corporate enterprises have started from Small and Medium enterprises. Small and medium enterprises are also playing major role in transforming the agri-based economy into industrialized one.

Globally, this sector remains a major driving force behind the fastest growing economies of the world like China and India. SMEs have also played major role in the economies of China and Japan. (http:// www. sbp.org.pk)

\section{2- Defining SMEs}

In Pakistan, definition of SMEs varies from different institutional point of view. As SBP plays a regulatory authority for the banks therefore banks follow the guidelines issued by the SBP for the banking industry. As per prudential regulations issued by State Bank of Pakistan SMEs are defined in terms of assets, number of employees and sales as per the nature of the industry like manufacturing, trading or services concern as under:

\begin{tabular}{|l|c|c|c|}
\hline & Trading & Manufacturing & Services \\
\hline No. of Employees up to & 50 & 250 & 250 \\
\hline Total Assets at cost up to & Rs.50 M & Rs $100 \mathrm{M}$ & Rs $50 \mathrm{M}$ \\
\hline Total Sales turnover up to & Rs $300 \mathrm{M}$ & Rs $300 \mathrm{M}$ & Rs $300 \mathrm{M}$ \\
\hline
\end{tabular}

Assets are considered excluding the cost of land and building. 


\subsection{Introduction to SME Financing}

The banking industry exposure towards SME sector is considered as the second largest one after the Corporate Sector. The outstanding credit portfolio of the banking industry to Small and Medium Enterprises during the year 2008 remained as under:

\begin{tabular}{|l|l|l|}
\hline \multicolumn{2}{|c|}{ Group of Banks } & \multicolumn{1}{c|}{ O/S amount } \\
\hline \multicolumn{2}{|c|}{ S. No. } & \multicolumn{1}{|c|}{ Loans to Small and Medium Enterprises (Rs. in M) } \\
\hline 1 & Public Sector Banks & 391,79 \\
\hline 2 & Private Sector Banks & 311,644 \\
\hline 3 & Specialized Banks & 9,411 \\
\hline 4 & Foreign Banks & 2,816 \\
\hline Total & DFls & $\mathbf{3 6 3 , 0 5 0}$ \\
\hline 5 & & 503 \\
\hline Grand Total & $\mathbf{3 6 3 , 5 5 4}$ \\
\hline
\end{tabular}

(SBP review on SMEs 2008)

\subsection{Risks Management in SMEs}

It is true that SMEs are considered more risky businesses and carry more chances of failure as compare to large sector enterprises due to the reason that they do not have the capacity to bear the unexpected economic shocks. Also their ability to pay impaired from time to time but if we look we will come to know at the same time they have better record of willingness to pay (Dr. Ishrat Hussain, April 2004).

Although there are many risks associated with the SME financing, it needs a comprehensive risk management process to control these all type of risks.

\section{Role of SBP in Growth of SMEs Financing}

State Bank of Pakistan is giving special focus to SME financing. During the last few years SME sector remained the main focus of the policy makers. SBP has taken various steps in the promotion of SME financing, such as:

- Establishment of SME Division

- Separate Set of Prudential Regulations for SMEs

- Establishment of SME Finance help Desk

- SME Finance Strategy

- Developed concept paper on SME Credit rating agency.

- Concept Paper on SME private equity Fund.

\section{Introduction to Jodia Bazaar Karachi}

Jodia Bazaar Karachi is considered as one of the major markets with respect to their business activities, which is surrounded by North Napier Market and Boltan Market also. It is considered as a major whole sale market which mainly consists of traders. These traders primarily deal in groceries, chemicals, dry fruits, plastic items, general importers, crockery importers, exporters of rice, grain traders (including pulses), second hand clothing etc.

Jodia Bazaar Karachi consist of thousands of SMEs, as it is the main business area where almost every bank either it is conventional or Islamic have its existence here.

If we discuss with the Credit Managers of different commercial Banks in the locality of Jodia Bazaar, we will come to know that their exposure in SME sector is much below than the present potential in the market. Our main focus is to highlight the factors with respect to Banks for not taking so much large exposure in the SME sector. 


\subsection{Data Analysis}

As we have already discussed that due to business potential in Jodia Bazaar almost every bank has its existence in the form of branch.

We have collected data from almost all banks which have their existence in the Jodia Bazaar.

The Banks from where the data have been collected includes:

- Five Major Banks

- Private Banks

- Foreign Banks

- Islamic Banks

In order to maintain the accuracy of Data, the data have mainly been collected from the Credit departments of the abovementioned banks.

Questionnaire contains fifteen questions; most of them are closed ended. Results are analyzed and presented in the form of Pie Charts. Details are as under:

\section{- Question No.1}

Question No. 1 was concerning the analysis of the Branch's total credit exposure in the SME Sector. The results are as under:
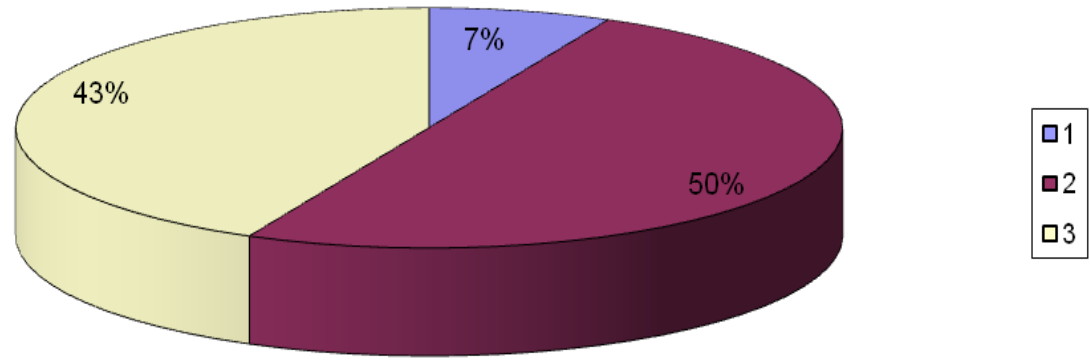

$50 \%$ of the results show that their total exposure in the SME sector remained within the range of Rs. 0.5 million to 1 billion. $43 \%$ shows that their exposure even remained below Rs. 0.5 Million. Only $7 \%$ results show that their exposure in the SME sector remained above 1 billion. 


\section{- Question No.2}

Question no. 2 explored the funded and non-funded exposure in the SME sector. The results are as under:

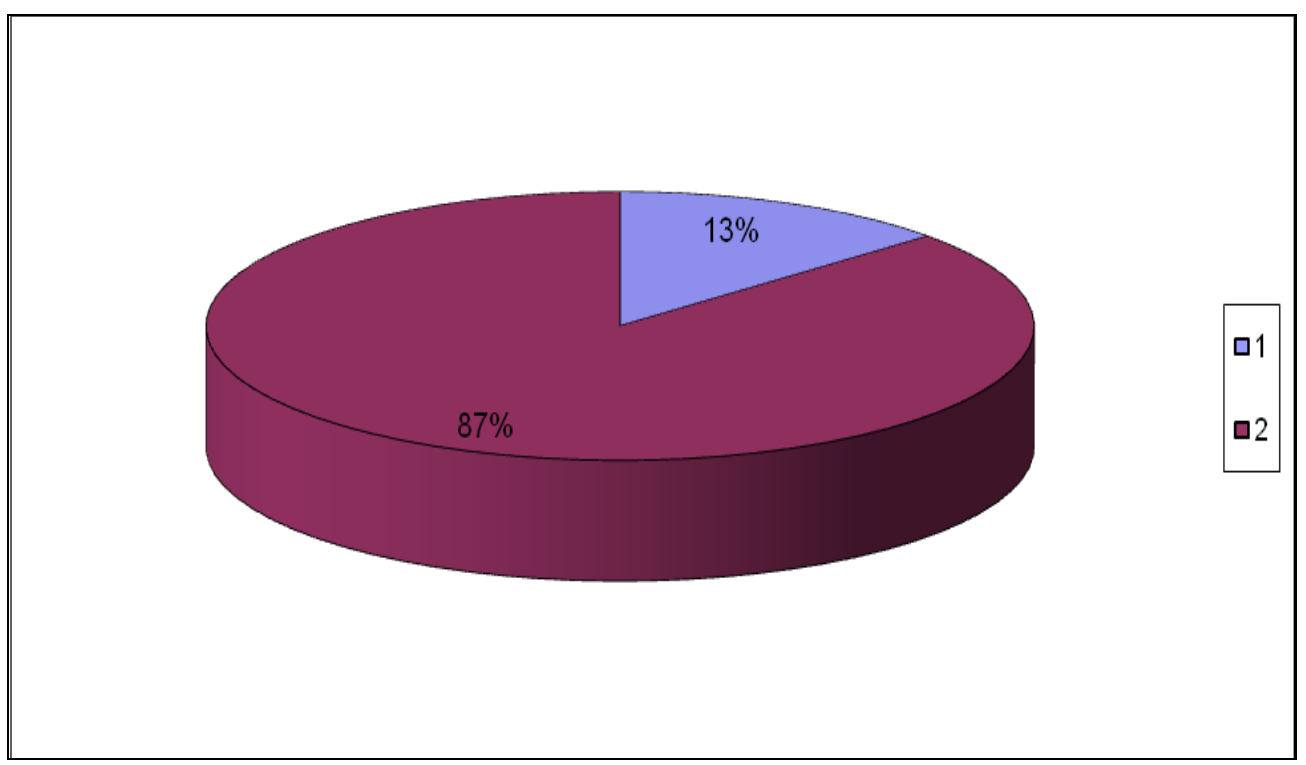

$87 \%$ of the respondents show that their major exposure in SME sector remained in non-funded facilities (like $\mathrm{L} / \mathrm{Cs}, \mathrm{L} / \mathrm{Gs}$ ) and $13 \%$ show that their major exposure in the SME sector remained in funded facilities.

\section{- Question No.3}

Question no. 3, was related to the availability of specialized credit products for the SME sector. The results are as under:
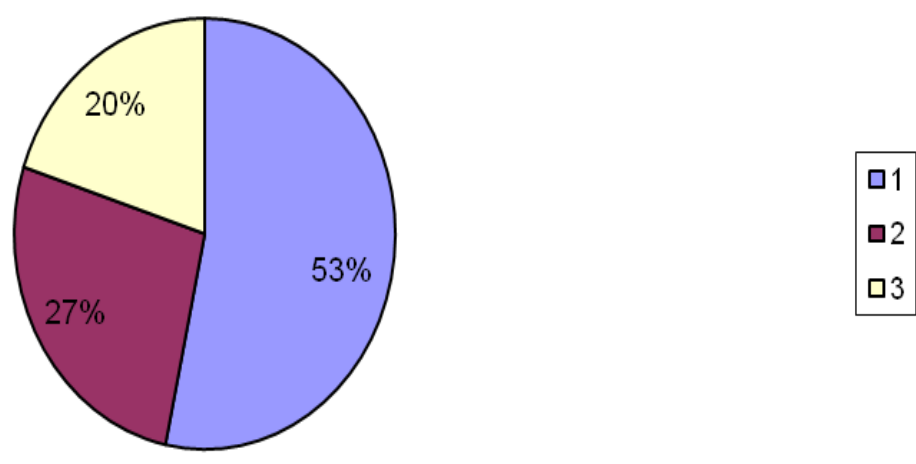

$53 \%$ of the respondents said yes about the availability of the specialized products for SMEs, $20 \%$ said No, while other $27 \%$ said that these are in the development process. 
- Question No.4

Question No. 4 was asked whether the SMEs of Jodia Bazaar offered collateral for availing the credit facilities from the banks. The results are as under:

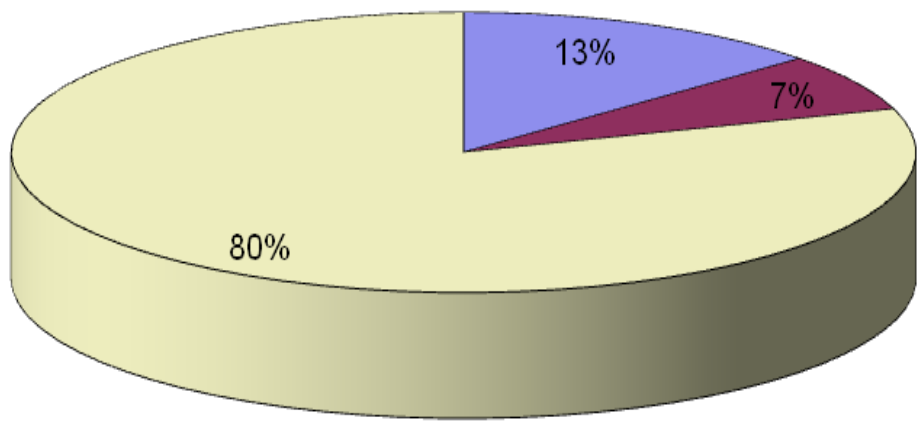

$13 \%$ said yes, while $7 \%$ say No, and $80 \%$ said that SMEs of Jodia Bazaar have the sufficient collateral to offer banks but they are normally reluctant to offer it.

\section{- Question No.5}

Question No. 5 was related to whether the SMEs of the Jodia Bazaar are maintaining their accounts properly. The results are as under:

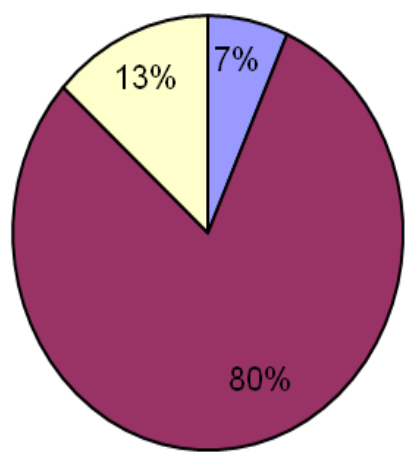


$80 \%$ of the respondents said that SMEs of the Jodia Bazaar are not maintaining their accounts properly, $17 \%$ said Yes but up to some extent they are doing so and only 7\% said Yes, they do so properly.

\section{- Question No.6}

Question No.6 was asked whether their Banks are properly marketing the SME products for the SMEs of the Jodia Bazaar. The results are as under:

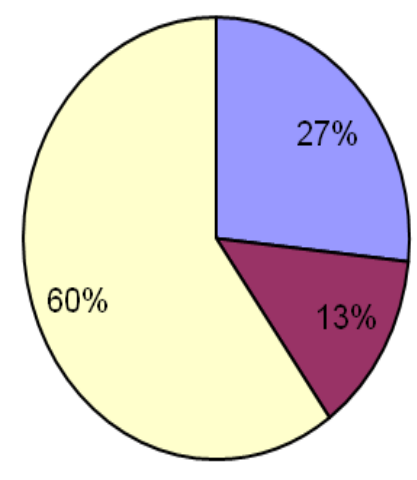

$60 \%$ results show that banks are mainly focusing upon the corporate sector, $27 \%$ said Yes, they are properly marketing their SME products, while $13 \%$ said No.

\section{- $\quad$ Question No.7}

Question no. 7 asked whether the SMEs of Jodia Bazaar have trained and technical staff to deal with the credit and banking affairs. The results are as under:

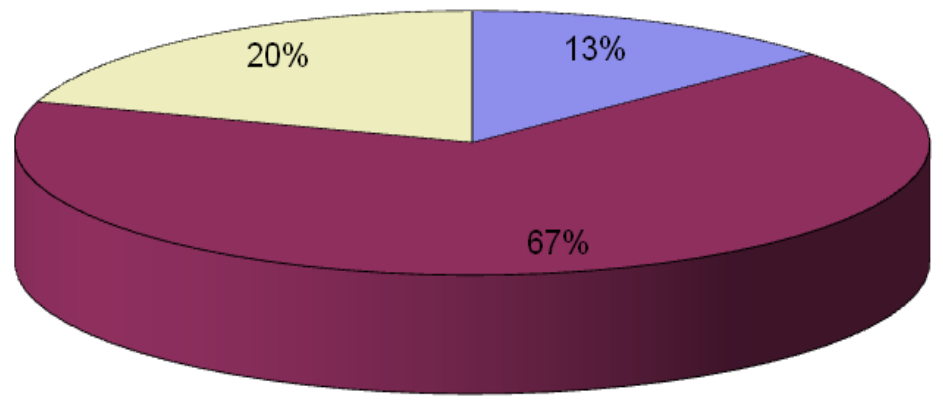


$67 \%$ said No, $13 \%$ said yes while $20 \%$ said up to some extent.

\section{- $\quad$ Question No.8}

In question no. 8, we asked about the most important issue for not taking the exposure in the SME sector. The results are as under:

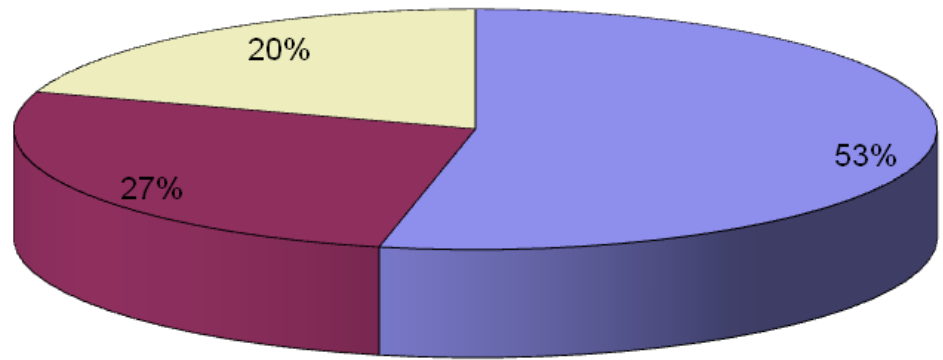

$80 \%$ of the respondents said that collateral issue is the main reason, $27 \%$ give weight age to proper maintenance of financial and accounts, while $20 \%$ said professional and trained staff.

\section{- Question No.9}

Question No. 9 was asked whether the SMEs of the Jodia Bazaar are running with succession planning. The results are as under: 


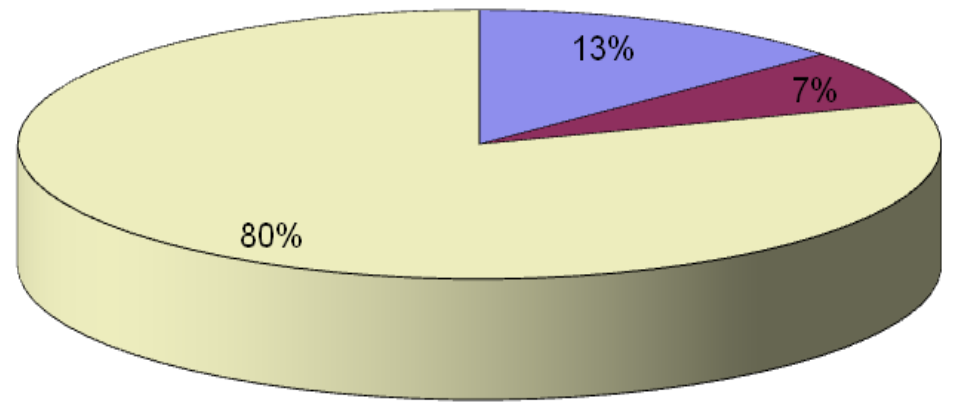

$80 \%$ show that most of them are running their family businesses, $13 \%$ said yes they have adequate succession planning, while only $7 \%$ said no.

- Question No.10

Question no. 10 was asked whether the proper information of SMEs like their credit rating etc is available to Bankers for making the credit decisions. The results are as under:

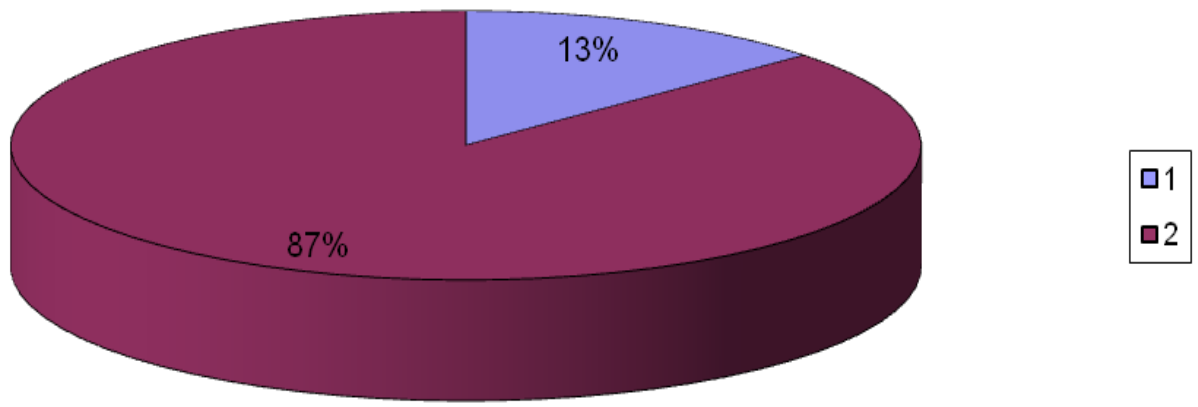

$87 \%$ respondents said No, while other $13 \%$ said Yes, it is available through informal channels.

\section{- Question No.11}

Question no .11 asked whether the SMEs of the Jodia Bazaar are able to bear the cost of the interest rates in the present scenario. The results are as under: 


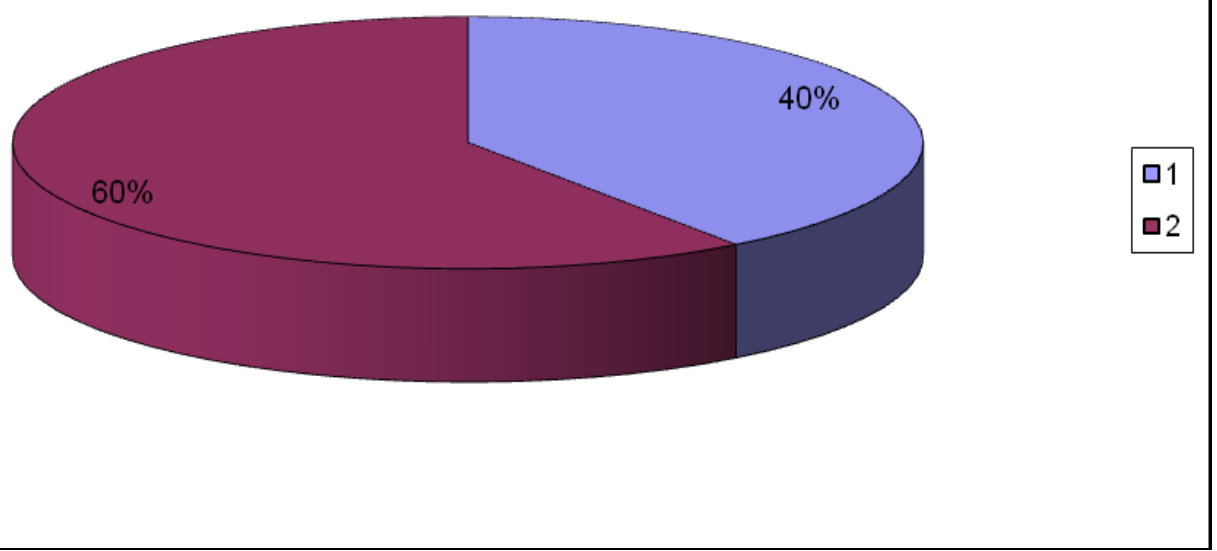

$60 \%$ said No, while the other $40 \%$ said Yes, they will be able to bear the cost of interest rates.

\section{- Question No.12}

Question No 12 was asked whether the SMEs of Jodia Bazaar provide correct information regarding their tax returns, profit margins, assets etc. The results are as under:

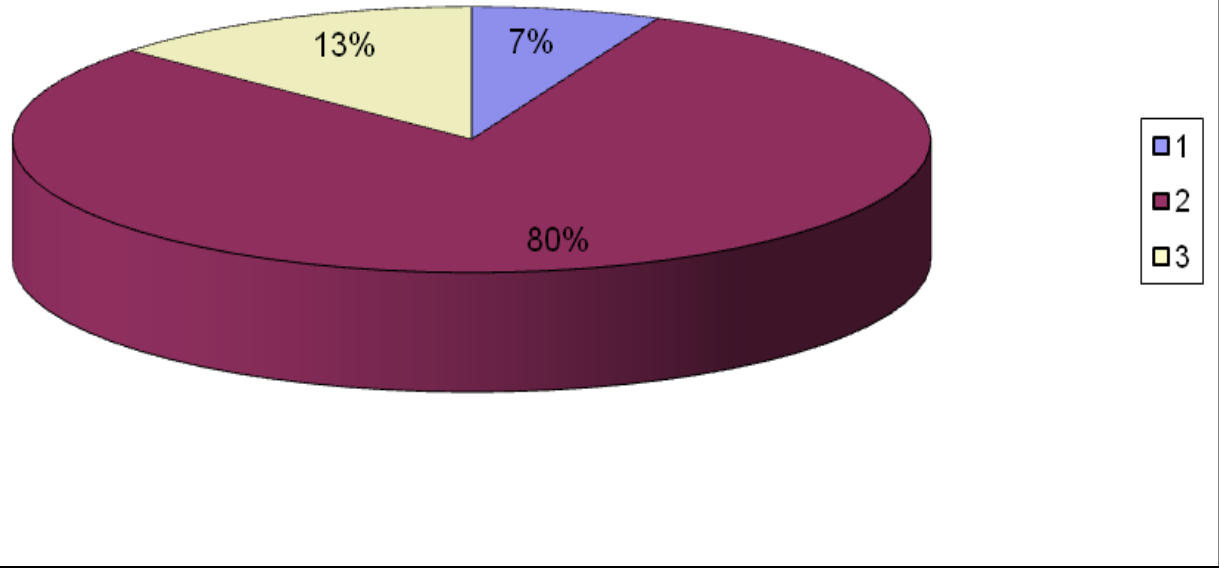

$80 \%$ of the respondents were of the view that they do not provide the correct information, $13 \%$ said up to some extent while other $7 \%$ said yes.

- Question No.13 
Question no.13 was asked whether you think that interest based factor is the one of the major factors for having less funded exposure in the Jodia Bazaar. The results are as under:

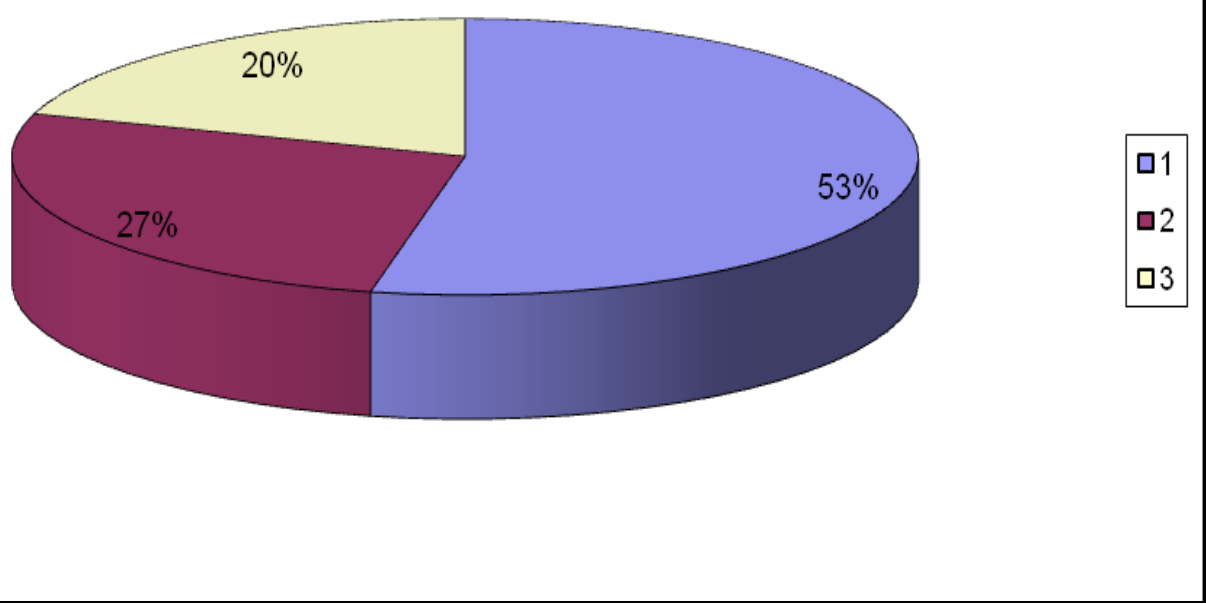

$53 \%$ said yes, $27 \%$ said No, while the remaining $20 \%$ said up to some extent.

\section{- Question No.14}

Question No 14 was asked whether the Banks are ready to take major exposure in SME financing in the present scenario. The results are as under:

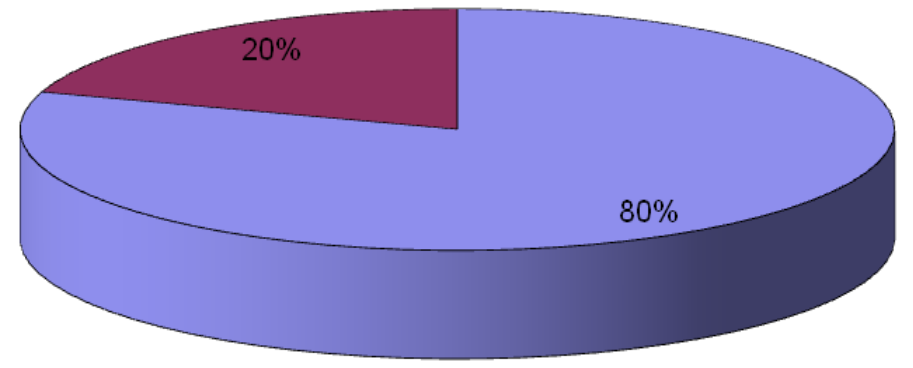

$80 \%$ of the respondents said yes, while other $20 \%$ said no.

\section{- Question No.15}

Question no. 15 was asked about the NPLs exposure in their Branches. The results are as under: 


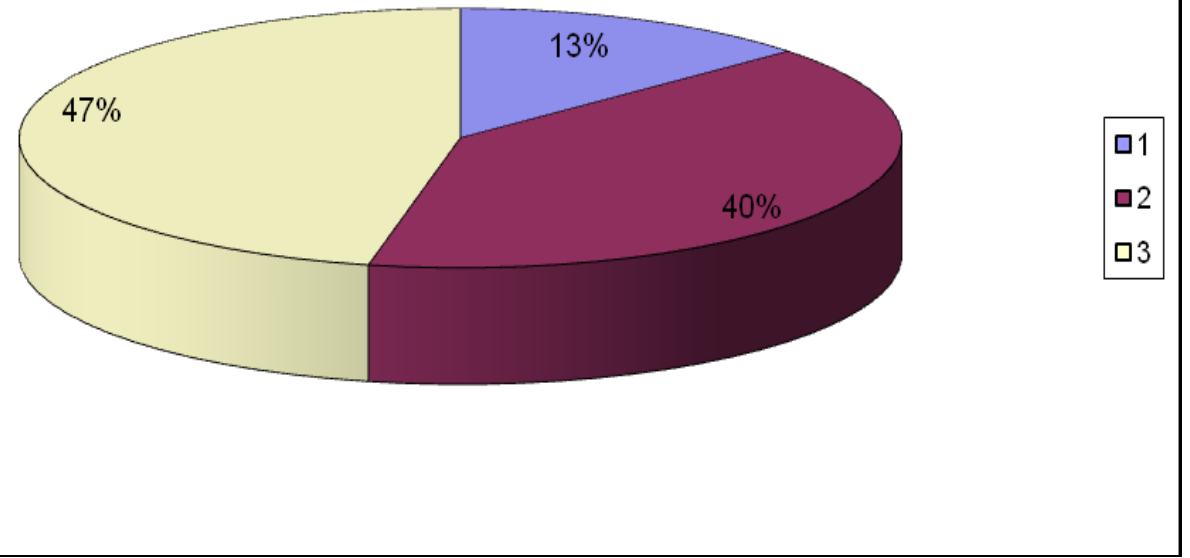

Results show that $47 \%$ said that their NPL exposure in the SME sector is less than $10 \%, 40 \%$ said that their NPLs are in the range of $15-20 \%$, while remaining $13 \%$ said they are more than $20 \%$.

\section{5- Conclusion}

As no one can deny the importance of SME sector either in a developed country or in a developing country, SMEs always play a major role in the growth of GDP, poverty elevation and employment generation. Developed countries like USA, Canada, Japan, Germany and Korea focused on their SME industries and got the best results.

Although Pakistan is also concentrating on SME sector but still there is need to do more in the same. This sector has a lot of potential which can play an important role in the progress of the country. Some specialized institutions like SME Bank, Small and Medium Enterprises (SMEDA) are playing major role in the growth of the SME sector. State Bank of Pakistan is also playing an active role so that access to credit facilities for the SME sector should be made more flexible. State Bank of Pakistan also encouraged the commercial Banks to develop the specialized products for the SME customers.

Jodia Bazaar Karachi is considered as the one of biggest whole sale Market in Karachi. This market also consists of thousands of SMEs. These SMEs have not access to the credit facilities by the banks despite the fact that almost every commercial bank has its branch in this vicinity.

Through our research, we have tried to find out the major reasons due to which Banks are reluctant to take exposure in SME sector. Major reasons are collateral issue, illiterate persons continuing their family business, not keeping the proper record of their accounts, manipulation of tax returns etc. in the light of this research, it can be safely concluded that SME sector of Jodia Bazaar can flourish exponentially only if these issues are looked into properly and resolved to the satisfaction of all the stakeholders.

\section{7- Recommendations}

Finally, we would like to suggest few recommendations which may play useful part for the banks to enhance their credit portfolio in SME sector:

- Banks should guide the customers when they provide documents for credit facilities. They should not ignore them as SME customers. 
- Banks should properly market their credit products related to SMEs.

- Banks should guide the customers to provide correct information as the correct information will also be beneficial for the customers for Approval of Credit facilities.

- Branches located in Jodia Bazaar should help their customers to learn how to maintain their accounts so that they will be acceptable for the Banks.

- SMEs which are reluctant to provide the collateral, their cash flows, repayment capacity and credit history should be focused.

- Banks should advice and encourage the SMEs (which can afford) to hire trained professionals for their businesses.

- No one can deny the importance of corporate sector but banks should also encourage the SMEs to avail the credit facilities from the Bank. 


\section{References}

Amruti S. Krishna (1997), Small Scale Industries: Policy, Rules and Regulations, Vinod Law Publications Lucknow.

Ahmed Rizvi, Shamim (2006), Banking Sector to retain Growth Momentum in 2006, Pakistan and Gulf Economist.

Dr. Akhtar, Shamshad, (Feb2007) Pakistan banking Sector Reforms: Performance and Challenges, addressed at Geneva.

Asian Productivity Organization (2001), Export Orientation for Small and Medium Enterprises Policies, Strategies and progammes.

BAL News Letter on SMEs, (June, 2009), Issue No. 15, Lahore, Pakistan.

Husain, Ishrat (April, 2004), Why lend to SMEs?, An address at SME workshop at Karachi.

Husain Ishrat (May, 2005), SME Financing Issues and Startergies, An address at SME Conference Lahore.

Ministry of Finance, Government of Pakistan (2007), Update on Pakistan's Economy, Islamabad.

Pratten Cliff, The Competitiveness of Small firms, Cambridge University Press.

Susman. I. Gerald, (2007), Small and Medium Sized Enterprises and the Global Economy, Edward Elgar Cheltenhan UK. 
Storey, D.J. (1994), Understanding the Small Business Sector, Routledge London and New York. http://www. smebank.com accessed on 05.10.2009

http://www.sbp.org.pk accessed on 05.10.2009

http://www.ibp.org.pk accessed on 24.02.2009 